Я. O. Бень, аспірант кафедри глобалістики, євроінтеграчії та управління начіональною безпекою, Начіональна академія державного управління при Президентові України

ORCID ID: 0000-0002-4222-813X

DOI: $10.32702 / 2306-6814.2020 .5-6.158$

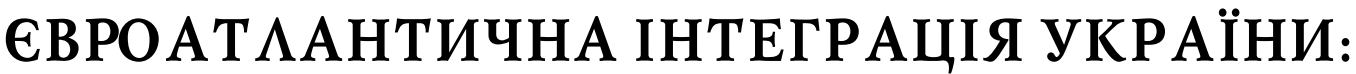 ТЕМПОРА $\triangle$ ВНА АИСКРЕТНІСТЬ
}

\author{
Ya. Ben, \\ applicant of the Department of Globalistics, European Integration and National \\ Security, National Academy of Public Administration, the President of Ukraine
}

\section{EURO-ATLANTIC INTEGRATION OF UKRAINE: TEMPORAL DISCRETION}

Устатті досліджено нормативно-правові та інституційні основи взаємодії України з Організацією Північно-Атлантичного договору впродовж 1992-2020 рр. Головну увагу зосереджено на Державних програмах співробітництва України з НАТО, а також на спільних органах (комісіях), призначених для реалізації запланованих заходів. Підкреслено особливе значення конституційного закріплення у 2019 р. євроінтеграційних намірів України. Детально розглянуто Річну національну програму під егідою Комісії Україна - НАТО на 2020 рік, яка змістовно наближена до Плану дій щодо набуття членства в НАТО. На цій основі виділено етапи євроатлантичної інтеграції України: 1992-1997 рр. - створення основ співробітництва України з НАТО; 1997-2005 рр. - інтенсифікація співробітництва України з Альянсом; 2005-2008 рр. - підготовка України до подання заявки на повноцінне членство в НАТО; 2008-2010 рр. - продовження співробітництва України з Альянсом з одночасним відтермінуванням її вступу на невизначений термін; 2010-2014 рр. - гальмування співробітництва України з НАТО за ініціативою української сторони; 2014-2019 рр. - повторна інтенсифікація співробітництва України з Альянсом із законодавчим (конституційним) закріпленням майбутнього членства в НАТО. Вказано, що 2020 р. започатковує новий етап у взаєминах України з НАТО, тривалість та специфіка якого поки що невизначено.

The article explores the legal and institutional framework for Ukraine's interaction with the North Atlantic Treaty Organization during the period 1992-2020. The focus is on the State Programs of Cooperation of Ukraine with NATO, as well as on joint bodies (commissions) designated for the implementation of the planned activities. The special importance of constitutional consolidation in 2019 of Ukraine 's European integration intentions is underlined. The Annual National Program under the auspices of the NATO-Ukraine Commission for 2020, which is substantially approximated to the NATO Membership Action Plan, is reviewed in detail.

The main elements of the legal framework of Ukraine's Euro-Atlantic integration are: Charter on a Special Partnership between Ukraine and the North Atlantic Treaty Organization, Ukraine-NATO National Cooperation Program, NATO-Ukraine Action Plan, Target plans to achieve the principles and objectives set out in the NATO-Ukraine Action Plan, State programs to inform the public about Ukraine's Euro-Atlantic integration issues, State program of training, retraining and advanced training of specialists in the field of European and Euro-Atlantic integration of Ukraine, Annual National Programs to Prepare Ukraine for Membership of the North Atlantic Treaty Organization, Annual National NATO-Ukraine Cooperation Programs, The concept of improving public awareness of Ukraine's Euro-Atlantic integration issues, etc.

The institutional basis for Euro-Atlantic integration of Ukraine during the same period is formed by: Coordinator-in-Chief of Ukraine's cooperation with NATO and the Western European Union in the military field (currently non-existent); NATO-Ukraine Commission; national co-ordinators of Ukraine's cooperation with the North Atlantic Treaty Organization (NATO) (currently non-existent); Commissioner for European and Euro-Atlantic Integration (currently non-existent); National Center for Euro-Atlantic Integration (disbanded); Interagency Commission on Preparation of Ukraine for NATO Accession (disbanded), EuroAtlantic Integration Commission of Ukraine.

On this basis, the stages of Ukraine's Euro-Atlantic integration were distinguished: 1992-1997 creation of the bases for Ukraine's cooperation with NATO; 1997-2005 - intensification of Ukraine's 
cooperation with the Alliance; 2005-2008 - preparing Ukraine for the application for full NATO membership; 2008-2010 - continued cooperation of Ukraine with the Alliance while delaying its accession indefinitely; 2010-2014 - slowing down Ukraine-NATO cooperation on the initiative of the Ukrainian side; 2014-2019 - re-intensification of Ukraine's cooperation with the Alliance with the legislative (constitutional) fixing of future NATO membership. It is stated that 2020 marks the beginning of a new stage in Ukraine's relations with NATO, the duration and specificity of which is still uncertain.

Ключові слова: єВроатлантична інтеграчія, НАТО, державні програми спіВробітництВа, норматиВнопраВовий базис, інституційний базис, етапиєВроатлантичної інтеграції.

Key words: Euro-Atlantic integration, NATO, national cooperation programs, legal framework, institutional framework, stages of Euro-Atlantic integration.

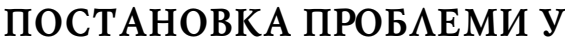 ЗАГААЬНОМУ ВИГАЯАІ}

Взаємодія України з Організацією Північноатлантичного договору, розпочавшись на початку $90-х$ років, демонструвала різні фази розвитку, проте не припинялась попри об'єктивні зміни державного керівництва та коригування національних інтересів. Водночас вона аж ніяк не являє собою лінійного процесу, що розвивається виключно по висхідній. Євроатлантична інтеграція України швидше $є$ хвилеподібним процесом. Якщо на рубежі 2008 р. Україна мала реальну можливість набути членства в Альянсі, то вже в 2010 р. інтенсивність діалогу сторін була знижена до рівня "співробітництва". Новий імпульс євроатлантичній інтеграції надала Революція Гідності з наступною конституційною фіксацією євроатлантичних намірів України. Задля прискорення процесу євроатлантичної інтеграції існують необхідні нормативно-правові та інституційні підстави. Проте навіть за сучасних умов чітких часових критеріїв вступу України до НАТО не визначено. Це стимулює подальшу наукову увагу до проблематики євроатлантичної інтеграції України, включно з виробленням необхідних практичних рекомендацій.

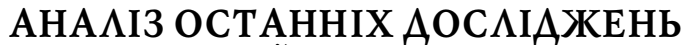 I ПУБАІКАЦІЙ ПО ТЕМІ}

Проблематика євроатлантичної інтеграції України залишається на порядку денному фрахової наукової дискусії з цих питань. Доречно вказати напраці (монографрії, дисертації, статті) вітчизняних науковців О. Білоуса, В. Бурдяк, Р. Войтович, А. Гетьмана, В. Горбуліна, О. Гоцур, В. Гречанінова, О. Деменка, І. Доцяка, В. Климончука, М. Кордона, О. Крапівіна, С. Ліпкевича, Л. Макаренко, Я. Малика, В. Мандрагелі, І. Мороза, О. Палія, О. Пошедіна, С. Прийдуна, І. Смирнової, В. Смолянюка, І. Тодорова, П. Тригуба, В. Шевельова, М. Юрчак та інших авторів. Проте динаміка євроінтеграційного процесу за участю України не дозволяє вирішувати проблеми майбутнього, опираючись лише на науковий доробок минулого. Саме тому осмислення євроінтеграційних перспектив України з урахуванням новітніх трендів (спрямованих як pro, так і contra євроатлантичного руху) має продовжуватися, ретранслюючись на загальносуспільні інтереси, оцінки та очікування.

\section{ЦІ $\Lambda$ І СТАТТІ}

Розкрити нормативно-правові та інституційні засади євроатлантичної інтеграції України. Здійснити періодизаціюєвроатлантичного курсу України. Виокремити періоди гальмування євроатлантичних зусиль. Вка- зати на необхідність вирішення нагальних завдань, пов'язаних з конкретизацією часових показників процесу набуття Україною повноцінного членства в НАТО.

\section{ВИКААА ОСНОВНОГО МАТЕРІААУ АОС АIАЖЕННЯ}

Україна має доволі розгалужену нормативно-правову та інституційну основи взаємодії з Організацією Північноатлантичного договору (НАТО), фрормування якої почалося відразу після здобуття незалежності. Про це свідчить така послідовність дій Української держави.

У лютому 1992 р. відбувся перший візит генерального секретаря НАТО М. Вернера до Києва, який офріційно запросив Україну до участі в Раді Північноатлантичного партнерства (з 1997 р. - Рада євроатлантичного співробітництва). 10.03.1992 р. Україна стала членом цієї організації. У липні 1992 р. Президент України Л. Кравчук вперше відвідав штаб-квартиру НАТО в Брюсселі.

1992 р.: відкрилося Посольство України в Брюсселі, яке стало сполучною ланкою в контактах між нашою державою та НАТО.

1994 р.: Україною було підписано розроблений НАТО Рамковий документ "Партнерство заради миру".

1994 р.: розпочалися безпосередні консультації України з НАТО у форматі "16+1", як це було передбачено Рамковим документом програми "Партнерство заради миру", з метою вивчення умов налагодження особливих відносин та встановлення "спеціального партнерства" між Україною і НАТО.

1995 р.: було підписано першу Індивідуальну програму партнерства між Україною і НАТО.

1996 р.: було створено посаду Головного координатора у співробітництві України з НАТО і Західноєвропейським союзом у військовій галузі.

1997 р.: було підписано Хартію про особливе партнерство між Україною та Організацією Північноатлантичного договору [1, с. 327-328]. Документ ставав головним регулятором відносин України з НАТО, визначав політичні зобов'язання сторін на найвищому рівні та необхідність розвивати відносини "особливого" та "ефективного" партнерства з метою сприяння більшій стабільності і просуванню спільних демократичних цінностей у Центрально-Східній Європі.

Того ж року було створено Комісію Україна НАТО (КУН), на яку було покладено відповідальність за прийняття рішень, розвиток відносин між Україною і НАТО, управління діяльністю зі співробітництва сторін. 
2001 р.: було прийнято Державну програму співробітництва України з НАТО на 2001-2004рр. [2].

2001 р.: було затверджено Положення про національних координаторів співробітництва України з Організацією Північноатлантичного договору (НАТО). 2002 р.: було підписано План дій Україна - НАТО. Документ визначив стратегічні цілі і пріоритети України для досягнення повної інтеграції у євроатлантичні структури безпеки та для створення стратегічних рамок для існуючого і майбутнього співробітництва України з НАТО відповідно до Хартії про особливе партнерство.

2003 р.: було запроваджено посаду Уповноваженого України з питань європейської і євроатлантичної інтеграції з метою забезпечення динамічного розвитку процесу входження України у європейський і євроатлантичний простір та узгодження діяльності і заходів, здійснюваних органами виконавчої влади у цій сорері. Крім того, було створено Національний центр з питань євроатлантичної інтеграції як консультативно-дорадчий (дорадчий) орган при Президентові України, метою якого було забезпечення послідовної реалізації курсу України на євроатлантичну інтеграцію, підготовка пропозицій щодо координації роботи органів виконавчої влади у цій сфрері.

2003-2009 рр.: Україна щорічно представляла Цільові плани для досягнення принципів і цілей, викладених у Плані дій Україна - НАТО. Плани фрормувались на основі пропозицій міністерств і відомств і містили конкретні завдання в різних сфрерах (внутрішньополітичні питання, зовнішня політика, реформування структур безпеки та оборони, інформування громадськості, інформаційна безпека, а також економічні та правові питання).

2004 р.: було прийнято Державну програму інорормування громадськості з питань євроатлантичної інтеграції України на 2004-2007 роки, а також Державну програму підготовки, перепідготовки та підвищення кваліфрікації фахівців у сфері європейської та євроатлантичної інтеграції України.

2005 р.: Україна, як учасниця "Партнерства заради миру", виявила прагнення набути членство в НАТО. На рівні КУН було прийнято рішення про активізацію діалогу щодо прагнень України до набуття членства в НАТО та здійснення нею відповідних реформ. У Воєнній доктрині України від 21.04.2005 р. було підкреслено: "Україна готується до повноправного членства в НАТО та ЄC" та "активізація євроатлантичної інтеграції України з орієнтацією на вступ до НАТО... належить до найважливіших пріоритетів як зовнішньої, так і внутрішньої політики".

2006 р.: було створено Національну систему координації співробітництва України з Організацією Північноатлантичного договору з метою забезпечення виконання пріоритетних завдань щодо дальшого розвитку відносин України з НАТО, поглиблення співробітництва України з державами - членами НАТО, досягнення критеріїв членства України в НАТО. У цьомуж році було створено Міжвідомчу комісію з питань підготовки України до вступу в НАТО як консультативно-дорадчий орган при Президентові України, складовий елемент національної системи координації України з НАТО.

У квітні 2008 р. на Бухарестському саміті Північноатлантичної ради НАТО на рівні глав держав було прий- нято рішення про те, що Україна і Грузія в майбутньому приєднаються до Альянсу, однак точних дат названо не було через жорстку позицію Німеччини і Франції. На думку лідерів цих держав, ідея вступу України до НАТО не підтримується всередині країни всіма політичними партіями, а також населенням Східної України. Тому Альянс відклав питання про приєднання цих двох країн до Плану дій щодо членства (ПДЧ), однак гарантував їхнє входження в НАТО "згодом" [3]. Крім того, у 2008 р. було підписано Державну цільову програму інформування громадськості з питань євроатлантичної інтеграції України на 2008-2011 рр.

Починаючи з 2009 р., річні цільові плани сторони замінили на річні національні програми співробітництва України з Альянсом.

2009 р.: було підписано Декларацію про доповнення Хартії про особливе партнерство.

2009-2010 рр.: підписувались Річні національні програми з підготовки України до набуття членства в Організації Північноатлантичного договору.

2010 рік та кілька наступних років стали періодом гальмування євроатлантичних дій України. Закон України від 01.07.2010 р. "Про засади внутрішньої і зовнішньої політики України" визначив позаблоковий статус держави, що зробило неможливою її євроатлантичну інтеграцію. На основі цього Закону були внесені відповідні поправки в чинне законодавство.

У квітні 2010 р. Президент України ліквідував Міжвідомчу комісію з питань підготовки України до вступу в НАТО та Національний центр з питань євроатлантичної інтеграції. У листопаді цього ж року ним було підписано Указ "Про забезпечення продовження конструктивного партнерства України з Організацією Північноатлантичного договору". Внаслідок цих та інших дій євроатлантична риторика Києва виявилась послабленою, проте не знятою з порядку денного реального політичного процесу.

2011-2019 рр.: підписувались Річні національні програми співробітництва Україна - НАТО (Річні національні програми під егідою КУН). Винятком став 2014 р., протягом якого на основі здобутків Революції Гідності 2013-2014 рр. відбувалось демократичне оновлення легітимних органів влади України - вибори глави держави, парламентські та місцеві вибори. Тогочасна політична криза в Україні своїм наслідком мала об'єктивне послаблення державної уваги до зовнішньополітичних проблем, зокрема до поточних питань євроатлантичного співробітництва.

23.12.2014 р. Верховна Рада України за поданням Президента України ухвалила Закон України "Про внесення змін до деяких законів України щодо відмови України від здійснення політики позаблоковості" [4]. Відповідно до цього Закону, у ст. 6 Закону України "Про основи національної безпеки України" від 10.06.2003 р. було відновлено положення, що серед пріоритетів національних інтересів є інтеграція України у європейський політичний, економічний, правовий простір з метою набуття членства в Європейському Союзі та в євроатлантичний безпековий простір, а також розвиток рівноправних взаємовигідних відносин з іншими державами світу в інтересах України.

У 2017 р. було введено в дію Концепцію вдосконалення інформування громадськості з питань євроатлантичної інтеграції України на 2017-2020 роки. 
21.06.2018 р. було прийнято Закон України "Про національну безпеку України", ст. 3 якого до фундаментальних національних інтересів України віднесла "інтеграцію України в європейський політичний, економічний, безпековий, правовий простір, набуття членства в $\Theta_{\text {вро- }}$ пейському Союзі та в Організації Північноатлантичного договору, розвиток рівноправних взаємовигідних відносин з іншими державами".

07.02.2019 р. положення про євроатлантичний курс нашої держави були внесені в Основний Закон [5]. Так, у Преамбулі зміненої Конституції України йдеться: "підтверджуючи європейську ідентичність Українського народу і незворотність європейського та євроатлантичного курсу України";

у розділі IV "Верховна Рада України" вказується: "визначення засад внутрішньої і зовнішньої політики, реалізація стратегічного курсу держави та набуття повноправного членства України в Європейському Союзі та в Організації Північноатлантичного договору";

у розділі V "Президент України" вказується: "Президент України є гарантом реалізації стратегічного курсу держави на набуття повноправного членства України в Європейському Союзі та в Організації Північноатлантичного договору";

у розділі VI "Кабінет Міністрів України. Інші органи виконавчої влади" вказується: уряд "забезпечує реалізацію стратегічного курсу держави на набуття повноправного членства України в Європейському Союзі та Організації Північноатлантичного договору".

30.10.2019 р. були затверджені нове Положення про Комісію з питань євроатлантичної інтеграції України, а такожії склад.

05.02.2020 р. український уряд схвалив Річну національну програму під егідою Комісії Україна - НАТО на 2020 рік (РНП-2020) [6]. Документ містить деякі інноваційні моменти. Зокрема, РНП-2020:

розроблена за методологією вимірювання досягнутих результатів. Розробка програми вперше здійснювалася за міжнародною методикою Results-Based Management (RBM, "Управління, орієнтоване на результат");

$\epsilon$ людиноцентричною, оскільки ставить у центр уваги безпеку людини, її права, свободи і законні інтереси;

містить механізм моніторингу виконання;

побудована за принципами, структурою та змістом планів дій щодо членства в НАТО країн, які раніше вступили до Альянсу.

РНП-2020 передбачає продовження реформування сектору безпеки та оборони України. Йдеться про приведення системи управління силами оборони, стратегічного та оперативного (бойового) управління, зв'язку, розвідки та спостереження до стандартів НАТО та сумісності із системами Альянсу, впровадження демократичного цивільного контролю над сектором безпеки і оборони, забезпечення умов для участі українських підприємств у багатонаціональних проектах НАТО у сорері розробки та виробництва озброєння і техніки тощо.

Крім того, РНП-2020 передбачає стимулювання подальших демократичних перетворень в Україні. Серед них, зокрема, формування ринкової економіки, забезпечення прозорості податкової системи, ефективне наукове співробітництво між Україною та країнами НАТО і ЄС, удосконалення системи боротьби з тероризмом, яка робить Україну надійним партнером у системі міжнародної безпеки, розвиток системи національної стійкості та захисту критичної інфраструктури тощо.

РНП-2020 максимально наближена за змістом та принципами до Плану дій щодо членства у НАТО. Це засвідчує її структура, що складається з п'яти розділів (як і ПДЧ): І. Політичні та економічні питання; ІІ. Оборона / Військові питання; III. Питання ресурсів; IV. Питання безпеки; V. Правові питання.

Виконання вказаної РНП спрямоване на досягнення цілі 17.2 Програми діяльності Кабінету Міністрів України, яка звучить наступним чином: "Україна відповідає принципам та критеріям, необхідним для набуття членства в Організації Північноатлантичного договору" [7].

РНП-2020, яка відрізняється від раніше існуючих програм, слід додатково оцінювати з позицій офіційного звернення України до НАТО у листопаді 2019 р. 3 проханням приєднатися до Програми розширених можливостей (EOP) [8]. Ця програма серед іншого надає доступ до розширеного діалогу сторін у сфрері розвідки, а також дозволяє громадянам країн-партнерів обіймати посади в штаб-квартирі НАТО або в командній структурі Альянсу. Програма об'єднує довкола НАТО клуб найближчих партнерів, які з різних причин не входять до Альянсу, але готові тісно взаємодіяти з ним. На сьогодні до програми ЕОР входять Грузія, Швеція, Фінляндія, Австралія та Йорданія.

Очікується, що РНП-2020 суттєво посприяє приєднанню України до Програми розширених можливостей загалом прискорить процес євроатлантичної інтеграції України.

Таким чином, можемо вказати на основні елементи нормативно-правового базису євроатлантичної інтеграції України [9]. На основі Хартії про особливе партнерство між Україною та Організацією Північноатлантичного договору були розроблені та певною мірою реалізовані Державна програма співробітництва України з НАТО, План дій Україна - НАТО, Цільові плани для досягнення принципів і цілей, викладених у Плані дій Україна - НАТО, Державні програми інфрормування громадськості з питань євроатлантичної інтеграції України, Державна програма підготовки, перепідготовки та підвищення кваліфікації фахівців у сфері європейської та євроатлантичної інтеграції України, Річні національні програми з підготовки України до набуття членства в Організації Північноатлантичного договору, Річні національні програми співробітництва Україна НАТО, Концепція вдосконалення інорормування громадськості з питань євроатлантичної інтеграції України. У 2018 р. "набуття членства в Організації Північноатлантичного договору" як "фундаментальний національний інтерес України" було зафріксовано в Законі України "Про національну безпеку України". У 2019 р. положення про євроатлантичний курс нашої держави були внесені в Конституцію України. У 2020 р. затверджено Річну національну програму під егідою Комісії Україна - НАТО, яка за структурою відповідає Плану дій щодо підготовки до членства в НАТО. 
Інституційну основу євроатлантичної інтеграції України за цей же період утворюють (утворювали): Головний координатор у співробітництві України з НАТО і Західноєвропейським союзом у військовій галузі (зараз не існує); Комісія Україна - НАТО; національні координатори співробітництва України з Організацією Північноатлантичного договору (НАТО) (зараз не існують); Уповноважений України з питань європейської і євроатлантичної інтеграції (зараз не існує); Національний центр з питань євроатлантичної інтеграції (розформований); Міжвідомча комісія з питань підготовки України до вступу в НАТО (розфрормована), Комісія з питань євроатлантичної інтеграції України.

Можемо виділити етапи євроатлантичної інтеграції України:

1992-1997 рр. - створення основ співробітництва України з НАТО;

1997-2005 рр. - інтенсифрікація співробітництва України з Альянсом;

2005-2008 рр. - підготовка України до подання заявки на повноцінне членство в НАТО;

2008-2010 рр. - продовження співробітництва України з Альянсом з одночасним відтермінуванням ії вступу на невизначений термін;

2010-2014 рр. - гальмування співробітництва України з НАТО за ініціативою української сторони;

2014-2019 рр. - повторна інтенсифрікація співробітництва України з Альянсом із законодавчим (конституційним) закріпленням майбутнього членства в НАТО.

Ймовірно, 2020 р. започатковує новий етап у взаєминах України з НАТО, проте його змістовне наповнення тільки розпочато.

\section{ВИСНОВКИ ТА ПЕРСПЕКТИВИ ПОАААЬШИХ РОЗВІАОК}

Попри значний обсяг державних заходів, виконаних упродовж усього періоду державно-політичної незалежності України, можемо констатувати невиконання головної мети євроатлантичної інтеграції - відсутність нашої держави у переліку держав-членів НАТО. Це контрастує з успіхами інших країн, які стали повноцінними членами Альянсу, маючи більш обмежені часові, інституційні, нормативно-правові та ін. ресурси.

За таких умов Україні слід виконати низку взаємопов'язаних заходів: забезпечити внутрішню консолідацію активних верств населення з питань євроатлантичної інтеграції та поширити іiї на електоральну громаду всіх регіонів, включно зі Східною Україною; нейтралізувати дії інших держав, які необгрунтовано критикують, а іноді й блокують євроінтеграційні зусилля Києва; поставити перед главами держав-членів НАТО питання при визначення чітких часових нормативів вступу України до НАТО; організувати діяльність держави і суспільства щодо своєчасного досягнення намічених темпоральних горизонтів. Усі ці питання мають отримувати належне наукове висвітлення та широку суспільну презентацію.

\section{Література:}

1. Смолянюк В.Ф. Хартія про особливе партнерство між Україною та Організацією Північноатлантичного договору. Юридична енциклопедія: в 6 т. К.: Українська енциклопедія, 1998. Т. 6.
2. Державні програми та плани співробітництва. URL: https://ukraine-nato.mfa.gov.ua/dokumenti/

3. Смирнова І.Є. Євроатлантична інтеграція України (в ракурсі рішень самітів у Бухаресті та Брюсселі. URL: file:///C:/Users/ADmin/Downloads/3362D1\%96-7105-1-10-20150703\%20(1).pdf

4. Рада скасувала позаблоковий статус України. URL: https://www.unian.ua/politics/1025042-radaskasuvala-pozablokoviy-status-ukrajini.html

5. Яковлєв А.А. Питання євроатлантичної інтеграції в сучасному конституційному процесі України. URL: file:/ / /C:/Users/ADmin/Downloads/180048-400274-1-PB.pdf

6. Уряд схвалив Річну національну програму Україна-НАTО нової якості. URL: http://www.mil.gov.ua/ news/2020/02/05/

7. Програма діяльності Кабінету Міністрів України. URL: https://program.kmu.gov.ua/

8. Україна звернулася до НАТО з проханням про участь у Програмі розширених можливостей. URL: https://www.eurointegration.com.ua/news /2019/11/ $1 / 7102532 /$

9. Ліпкевич С.Я. Правові аспекти співробітництва України з HATO. URL: http://vlp.com.ua/files / 28_5.pdf

\section{References:}

1. Smolianiuk, V.F. (1998), "Charter on special partnership between Ukraine and the North Atlantic Treaty Organization", Yurydychna entsyklopediia [Legal Encyclopedia], Ukrains'ka entsyklopediia, Kyiv, Ukraine.

2. Ukraine - NATO (2020), "State programs and plans of cooperation", available at: https://ukraine-nato.mfa.gov.ua/dokumenti / (Accessed 25 Feb 2020).

3. Smyrnova, I.Ye. (2018), "Ukraine's Euro-Atlantic integration (in view of the Bucharest and Brussels summits)", available at: https://periodicals.karazin.ua/ politology/article/download/3362/2935/(Accessed 25 Feb 2020).

4. UNIAN (2014), "The Council canceled Ukraine's nonaligned status", available at: https://www.unian.ua/ politics / 1025042-rada-skasuvala-pozablokoviy-statusukrajini.html (Accessed 25 Feb 2020).

5. Yakovliev, A.A. (2019), "Issues of Euro-Atlantic integration in Ukraine's current constitutional process", available at: http://journals.uran.ua/sr_law/article / download/180048/180589 (Accessed 25 Feb 2020).

6 . Ministry of Defence of Ukraine (2020), "The Government endorsed the New Ukraine-NATO Annual National Program of New Quality", available at: http://www.mil.gov.ua/news /2020/02/05/(Accessed 25 Feb 2020).

7. Cabinet of Ministers of Ukraine (2020), "Program of activities of the Cabinet of Ministers of Ukraine", available at: https://program.kmu.gov.ua/ (Accessed 25 Feb 2020).

8. YevroPravda (2019), "Ukraine has requested NATO to participate in the Enhanced Capability Program", available at: https://www.eurointegration.com.ua/ news /2019/11/1/7102532/(Accessed 25 Feb 2020).

9. Lipkevych, S.Ya. (2008), "Legal aspects of Ukraine's cooperation with NATO", available at: http:// vlp.com.ua/files/28_5.pdf (Accessed 25 Feb 2020). Стаття надійшла до редакиї 02.03.2020 p. 